\title{
Neuroprotective effect of melatonin in mice with toxic cuprizone model of demyelination and possible pathways of its realization
}

\author{
Labunets I. F., Rodnichenko A. E., Melnyk N. O., Utko N. O. \\ State Institute of Genetic and Regenerative Medicine National Academy of Medical Sciences of Ukraine, Kyiv, Ukraine \\ e-mail: irina_labunets@ukr.net
}

\section{ABSTRACT}

The search for tools that increase the effectiveness of cell therapy of demyelinating pathology is relevant. They may be preparations that affect the pathogenetic factors of this pathology, in particular, the pineal hormone melatonin.

The PURPOSE of the study is to evaluate the involvement of immune system and antioxidant defense in the implementation of the protective effects of melatonin on morphofunctional disorders in the central nervous system induced by neurotoxin cuprizone.

MATERIALS AND METHODS. The toxic demyelination model was induced on 129/Sv mice at the age of 3-5 months by adding cuprizone to food for 3 weeks. Since the $7^{\text {th }}$ day of cuprizone administration, melatonin was injected intraperitoneally at 6 p.m. daily, at a dose of $1 \mathrm{mg} / \mathrm{kg}$. In the brain of mice, the proportion of $\mathrm{CD}^{+}$, Nestin ${ }^{+}$cells and phagocytic macrophages, the content of malondialdehyde and the activity of antioxidant enzymes was determined. Blood serum was tested for thymic hormone thymulin levels. In the animals, we evaluated the structure of the brain and spinal cord neurons by Nissl staining of histological sections as well as analyzed behavioural reactions in the «open field» test.

RESULTS. In the brain of the mice receiving cuprizone, the proportion of $\mathrm{CD} 3^{+}$and Nestin ${ }^{+}$cells, active macrophages and malondialdehyde content increased, glutathione peroxidase and glutathione reductase levels decreased. In the brain and spinal cord of the mice with a cuprizone diet, the proportion of altered neurons increased, and motor and emotional activity decreased. The administration of melatonin results in a decrease in the relative number of $\mathrm{CD} 3^{+}$cells, active macrophages and malondialdehyde content, increased activity of glutathione peroxidase, glutathione reductase and level of thymulin. In such mice, the proportion of unchanged neurons increases as the number of Nestin+ cells decreases and behavioural responses are also improved.

CONCLUSIONS. The neuroprotective effect of melatonin in demyelinating pathology is realized through the factors of the immune system and oxidative stress. The results may be useful in the development of new biotechnological approaches to the treatment of demyelinating pathology, in particular, multiple sclerosis.

KEY WORDS: cuprizone; melatonin; neuron; T-lymphocytes; brain macrophages; thymulin; antioxidant enzymes

Among the demyelinating diseases of the central nervous system (CNS), particular attention is paid to multiple sclerosis, which affects mainly young people and occupies the $2^{\text {nd }}$ place among diseases of the nervous system causing disabilities in Ukraine [1]. Existing approaches to the pharmacotherapy of this pathology are not always effective, and the long-term use of drugs is accompanied by significant side effects.

A promising trend in the treatment of multiple sclerosis may be the use of transplanted stem cells of various sources, as well as approaches aimed at activating endogenous neural stem cells (NSCs) or progenitors in the main neurogenic zones of the brain [2,3]. In order to increase the effectiveness of such therapy, it is important to use a tools that can affect such pathogenetic factors of neural cell injury (NSCs, neurons, oligodendrocytes) as neuroinflammation, oxidative stress, activated immune cells (T lymphocytes, macrophages) $[4,5]$.

One such agent may be the pineal hormone melatonin, which provides a wide range of biological activity in vivo. It regulates the biorhythms of 
the body's functions, controls the immune and endocrine systems, has antioxidant, antiapoptotic, anti-inflammatory and neurotrophic properties $[6,7]$. The remyelinating effect of melatonin in mice with an experimental model of multiple sclerosis was found [8]. According to our preliminary data, melatonin has a protective effect on the CNS neurons in mice with toxic cuprizone demyelination model [9]. However, mechanisms of such influence of melatonin remain poorly studied.

The purpose of the work is to evaluate the participation of immune system factors and antioxidant defense in the implementation of the protective effect of melatonin on morpho-functional disorders in the central nervous system induced by neurotoxin cuprizone.

\section{MATERIALS AND METHODS}

Animals. Experiments were carried out on 3-5-month-old female $129 /$ Sv mice $(n=24)$ from the vivarium of the Institute of Genetic and Regenerative Medicine of the National Academy of Medical Sciences of Ukraine. The mice were kept in standard vivarium conditions at a fixed 12:12 hours light mode. Biological samples for experiments was obtained from mice in the morning after euthanasia by decapitation under ether anaesthesia. All experiments with animals were performed in compliance with the Law of Ukraine «On the Protection of Animals from Cruelty» (dated February 21, 2006) and the «European Convention for the Protection of Vertebrate Animals Used for Experimental and Other Scientific Purposes» (Strasbourg, 1986).

Experimental models. To induce demyelination in the central nervous system, neurotoxin cuprizone [bis(cyclohexanone)-oxaldihydrazone] (Sigma-Aldrich, Germany) was used. Cuprizone is a copper chelator that damages the copper enzymes in mitochondria of mature oligodendrocytes, which leads to their apoptosis [10,11]. Mice received cuprizone with food daily during three weeks (at a dose of $0.2 \%$ of daily meal). In young mice, with such time of neurotoxin application, not only demyelination occurs in the structures of the central nervous system [11], but also, according to our previous data, changes in the structure of neurons of the cerebral cortex, cerebellum and spinal cord [12-15]. According to the literature, pathological changes in the central nervous system of the animals with a cuprizone-induced model of demyelination are similar to manifestations of demyelinating disease in humans (in particular, multiple sclerosis). They are primary damage of mature oligodendrocytes and their death; absence of autoimmune damage to myelin; oxidative stress; the infiltration in the damage zones consists mainly of cells of microglia/ macrophages and to a lesser extent T-lymphocytes; association of structural and functional changes of the central nervous system [11, 16].

Experimental groups. Mice were divided into the following groups: 1 - intact untreated animals that had a standard diet; 2 - mice receiving cuprizone and $0.9 \% \mathrm{NaCl}$ solution (control group); 3 - mice receiving cuprizone and melatonin injections (Sigma, USA). Melatonin was injected, starting from the seventh day of receiving the cuprizone, daily at 6 p.m., intraperitoneally, at a dose of $1 \mathrm{mg} / \mathrm{kg}$. The scheme of administration of the melatonin was based on the data we received earlier regarding the development of changes in motor activity and the structure of neurons in CNS after 7 days of cuprizone treatment $[15,17]$. Each experimental group consisted of 8 mice. The studies were conducted for 21 days after the start of the cuprizone treatment.

Phenotyping of the brain cells for CD3 marker was performed using the PE-conjugated mouse monoclonal antibodies at a working concentration of $0.5 \mu \mathrm{g} / \mathrm{mL}$ (Becton Dickinson, USA). Cell samples without antibodies were used as a control. The content of neural stem cells was determined by the expression of Nestin. For this purpose, the homogenate of the brain was fixed for 10 minutes at room temperature with a $4 \%$ solution of paraformaldehyde in $0.1 \mathrm{M}$ phosphate buffered saline (PBS) at $\mathrm{pH}=7.4$. Cells were permeabilized for 15 minutes with Perm/Wash buffer (Becton Dickinson, USA). To identify Nestin ${ }^{+}$cells, we used PEconjugated mouse anti-nestin monoclonal antibodies (Becton Dickinson,
USA). As a control, we used cell samples without antibodies. Measuring was performed with BD FACSAria cell sorter (Becton Dickinson, USA) using BD FACSDiva 6.1.2 software.

Phagocytic activity of murine brain macrophages was determined by phagocytosis of latex beads $[14,15,18,19]$. Briefly, the brain was homogenized in a PBS and cell suspension was passed through $100 \mu \mathrm{m}$ cell strainer. Cells were cultured at a temperature of $+37^{\circ} \mathrm{C}$ in a humidified atmosphere with a concentration of $5 \% \mathrm{CO}_{2}$ for one hour in a RPMI1640 culture medium (Sigma, USA), supplemented with $10 \%$ fetal bovine serum (Sigma, USA), antibiotics (100 units/ml penicillin, $100 \mu \mathrm{g} / \mathrm{ml}$ streptomycin), $2 \mathrm{mM}$ L-glutamine. At the end of the culturing period, the adherent cells were trypsinized using a $0.25 \%$ trypsin/EDTA solution. The total cell number was counted in a Goryaev chamber. $0.2 \mathrm{~mL}$ of this suspension was plated on coated glasses at concentrations $2.5 \cdot 10^{6} \mathrm{cell} / \mathrm{s} / \mathrm{mL}$ and incubated for 60 minutes at $+37^{\circ} \mathrm{C}$ in a humidified atmosphere with $5 \% \mathrm{CO}_{2}$. After incubation, $0.2 \mathrm{~mL}$ of a latex suspension $\left(2.5 \cdot 10^{8}\right.$ beads/ $\mathrm{mL}$ ) was added to the resulting monolayer in a RPMI- 1640 medium and incubated for 45 minutes at $+37^{\circ} \mathrm{C}$ in a humidified atmosphere with $5 \%$ $\mathrm{CO}_{2}$. After incubation, the glass was fixed in $4 \%$ paraformaldehyde and stained by Romanovsky-Giemsa. Under a light microscope, at least 200 macrophages were counted and phagocytic activity (PA) - the number of latex beads captured by macrophages divided by 100 counted cells, and the phagocytic index $(\mathrm{PI})$ - the percentage of cells capable of phagocytosis of latex beads, were determined.

The thymus endocrine function was evaluated by the blood level of thymic serum factor (thymulin) in the test of restoration sensitivity to the azathioprine by rosette-forming splenocytes of the thymectomized mice (Sigma, USA) [20, 21]. To remove the macromolecular inhibitor, the serum was centrifuged through an ultrafilter CF-25/50 (Amicon, USA). The titre of thymulin $\left(\log _{2}\right)$ was considered the last dilution of serum, which causes a $50 \%$ reduction in the number of rosette-forming cells versus control.

Activity of oxidative stress and antioxidant defense factors in the brain. In the homogenates of the cerebellum, the content of malondialdehyde (MDA) was investigated [22]. The activity of antioxidant enzymes was measured in supernatants of murine brain cerebellum homogenates (centrifugation at $10,000 \mathrm{~g}$ for $20 \mathrm{~min}$ ) on a spectrophotometer $\mu$ Quant (Bio-Tek, USA) [16, 17]. The activity of superoxide dismutase (SOD) was expressed in standard units per $1 \mathrm{mg}$ of protein for $1 \mathrm{~min}$, catalase - in micromoles of utilized $\mathrm{H}_{2} \mathrm{O}_{2}$ per $1 \mathrm{mg}$ of protein for $1 \mathrm{~min}$; glutathione peroxidase and glutathione reductase - in nanomoles of oxidized NADPH per $1 \mathrm{mg}$ protein in $1 \mathrm{~min}$. The protein content in the cerebellum was measured by Lowry method.

For morphological studies of the CNS in mice, the tissue was dehydrated and embedded with paraffin wax mixture. Then, from the paraffin blocks, 5-7 $\mu \mathrm{m}$-thick histological sections were made using an automated rotary microtome. Later, the histological sections were stained with toluidine blue by Nissl $[12,13]$.

At morphometric analysis, the percentage of unchanged neurons and neurons with moderate (reactive) and severe (destructive) structural changes was determined $[12,13]$. The changes in the size and shape of the body and nucleus of the neuron, especially the location of the chromatophilic substance, were evaluated.

Behavioural responses in mice were investigated in the "open field» test, which is one of the adequate criteria for evaluating motor disorders when cuprizone are used [24]. This test also enables to assess the emotional activity of animals [25]. It has been shown that mice are an adequate model object for the study of emotional behaviour and its violations, since the neurochemical and molecular mechanisms that are at their basis are similar to those of humans [26].

Statistical data analysis. The analysis of the data was performed using the Statistica 7.0 software (StatSoft Inc., USA). The differences between the groups were assessed using Student's t-test [27]. The results are presented as means and standard error of mean $(\mathrm{M} \pm \mathrm{m})$. The difference between the parameters was considered statistically significant at a value of $p<0.05$. 


\section{RESULTS AND DISCUSSION}

Changes in the factors of immune system in mice that received cuprizone and melatonin. A significant increase in the number of $\mathrm{CD}^{+}$ cells, macrophages and their activity in the brain of mice with a cuprizone diet was established (Table 1). After the administration of melatonin, the proportion of T-cells and the phagocytic activity of the macrophages decreases to the values of the intact group, but the percentage of phagocytic cells remains high. Under the influence of melatonin, the content of thymulin in the blood serum significantly increased (Table 1).

Indices of oxidative stress and antioxidant defense in the brain of mice that received cuprizone and melatonin. It has been established that in the cerebellum of mice with cuprizone diet, the MDA content significantly increases relatively to the intact group, while the activity of glutathione peroxidase and glutathione reductase decreases (Table 2). After the injections of melatonin, the MDA content is reduced to the values of the intact group. Reduced activity of glutathione peroxidase and glutathione reductase is restored under the influence of melatonin, while the activity of glutathione reductase even exceeds the indices of the intact group (Table 2). The activity of SOD and catalase does not differ between the experimental groups of animals.

The content of Nestin ${ }^{+}$cells in the brain and morpho-functional changes of CNS in mice receiving cuprizone and melatonin.

An increase in the proportion of Nestin ${ }^{+}$cells in the brain of the mice that received cuprisone and its reduction to the values of intact animals after the introduction of melatonin was established (Fig. 1).

After receiving the cuprizone, obtained results showed structural changes in the cortical, cerebellar and spinal neurons (Fig. 2 D, E, F). Compared to intact mice (Fig. 2 A, B, C), most of the neurons in the CNS had a pathological change within the field of vision. The nucleus is intensely stained, the nucleoli are not defined, the size of the pericarion and the nucleus is significantly reduced that characterize neurons with distinct changes. In mice that received an injection of melatonin and cuprizone (Fig. 2 G, H, J), in the majority of the studied neurons, moderate changes were observed that had signs of compensatory-adaptive nature. In these neurons, hypochromic cytoplasm, as well as the increase in the size of the nuclei and nucleoli, which are characteristic of their active state, were determined.

The morphometry results of cortex and cerebellum, lumbar spinal cord of the experimental mice receiving melatonin, demonstrated changes in the ratio of neurons with varying degrees of structural changes unchanged, with moderate and severe changes (Fig. 3). Thus, after administration of melatonin, in the investigated parts of the central nervous system there is a decrease in the proportion of neurons with severe structural changes and, conversely, an increase in the proportion of unchanged neurons and reactive moderate structural changes.

The results indicate that melatonin increases the activity of neurons, which is reflected in the increase in the number of unchanged and moderately changed neurons. This means that the activating effect of melatonin on synthetic processes in the brain and spinal cord in mice receiving cuprizone was established.

The study of behavioural reactions found that, in mice receiving cuprizone, motor and emotional activity was significantly reduced in comparison with the intact group (Fig. 4). Administration of melatonin to the test animals causes a significant increase in these parameters, in particular, emotional activity increased to the values of the intact group.

Thus, as a result of our experimental studies, the positive effect of melatonin on structural and functional disorders in the central nervous system induced by neurotoxin cuprizone has been established, as well as the importance of the factors of the immune system and antioxidant defense in the implementation of such an effect of the hormone.

The literature data prove that cuprizone induces demyelination of neuron axons in different parts of the central nervous system $[8,10,11]$. According to the results of our studies, after a three-week treatment with
Table 1. The proportion of CD3+ cells and active macrophages in the brain, as well as the level of thymulin in the blood of the experimental groups of mice $(\mathrm{M} \pm \mathrm{m})$.

\begin{tabular}{|l|c|c|c|}
\hline \multirow{2}{*}{\multicolumn{1}{|c|}{ INDEX }} & \multicolumn{3}{c|}{ EXPERIMENTAL GROUPS } \\
\cline { 2 - 4 } & UNTREATED & $\begin{array}{c}\text { CUPRIZONE + } \\
\mathbf{0 , 9} \% \text { NaCL }\end{array}$ & $\begin{array}{c}\text { CUPRIZONE + } \\
\text { MELATONIN }\end{array}$ \\
\hline CD3 ${ }^{+} \%$ & $0.9 \pm 0.1$ & $2.6 \pm 0.2^{*}$ & $0.9 \pm 0.1^{\#}$ \\
\hline PI, \% & $47.1 \pm 2.1$ & $65.0 \pm 3.5^{*}$ & $55.2 \pm 2.5^{\star \#}$ \\
\hline PA, a. u. & $2.5 \pm 0.1$ & $2.3 \pm 0.2^{\star}$ & $2.6 \pm 0.1^{\#}$ \\
\hline Thymulin, $\log _{2}$ & $5.5 \pm 0.2$ & $6.1 \pm 0.5$ & $8.3 \pm 0.6^{*}$ \\
\hline
\end{tabular}

Notes: ${ }^{*}-p<0.05$ compared to untreated group; $\#-p<0.05$ compared to cuprizone group; $P I$ - phagocytic index, $P A$ - phagocytic index.

Table 2. Indices of oxidative stress and antioxidant protection in the cerebellum of experimental groups of mice $(\mathrm{M} \pm \mathrm{m})$.

\begin{tabular}{|c|c|c|c|}
\hline \multirow[b]{2}{*}{ INDEX } & \multicolumn{3}{|c|}{ EXPERIMENTAL GROUPS } \\
\hline & INTACT & $\begin{array}{l}\text { CUPRIZONE + } \\
0,9 \% \mathrm{NaCL}\end{array}$ & $\begin{array}{c}\text { CUPRIZONE + } \\
\text { MELATONIN }\end{array}$ \\
\hline $\begin{array}{l}\text { Malondialdehyde } \\
\text { (nM/mg) }\end{array}$ & $3.8 \pm 0.2$ & $5.0 \pm 0.3^{*}$ & $3.7 \pm 0.2^{\#}$ \\
\hline $\begin{array}{l}\text { Superoxide dismutase } \\
(\mathrm{U} / \mathrm{mg} \cdot \mathrm{min})\end{array}$ & $8.5 \pm 0.5$ & $8.2 \pm 0.3$ & $8.9 \pm 0.4$ \\
\hline Catalase $(\mu \mathrm{M} / \mathrm{mg} \cdot \mathrm{min})$ & $2.9 \pm 0.1$ & $2.3 \pm 0.2$ & $2.2 \pm 0.3$ \\
\hline $\begin{array}{l}\text { Glutathione peroxidase } \\
\text { (nM/mg・min) }\end{array}$ & $12.5 \pm 0.5$ & $12.1 \pm 0.3^{*}$ & $13.6 \pm 0.4^{\#}$ \\
\hline $\begin{array}{l}\text { Glutathione reductase } \\
\text { (nM/mg・min) }\end{array}$ & $22.5 \pm 0.6$ & $18.8 \pm 0.5^{\star}$ & $28.5 \pm 0.8^{\star \#}$ \\
\hline
\end{tabular}

Notes: ${ }^{*}-p<0.05$ compared to untreated group:

$*-p<0.05$ compared to cuprizone group.

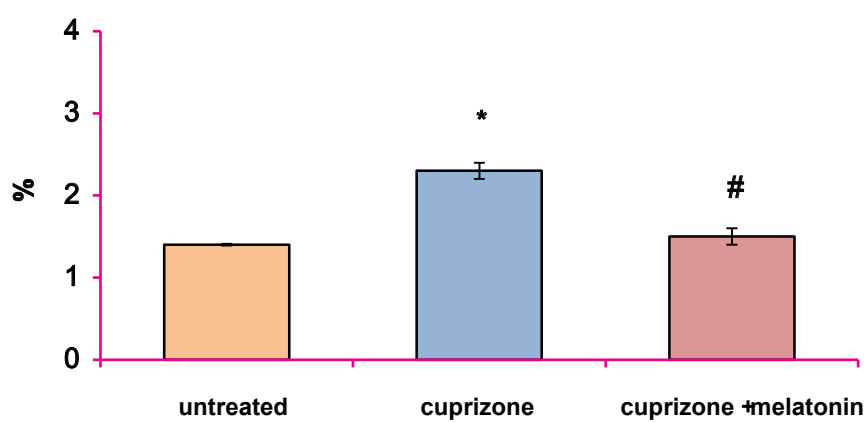

人

Fig. 1. The proportion of Nestin+ cells in the brain of mice that received cuprizone and melatonin.

Notes: * $-p<0.05$ compared to untreated group;

$\#-p<0.05$ compared to the cuprizone group.

this cuprizone, not only demyelination [15], but neurodegenerative changes in the cerebral cortex and cerebellum, lumbar zone of the spinal cord, develop. Attention is drawn to a significant increase in the proportion of Nestin ${ }^{+}$ cells in the brain of mice with a cuprizone treatment. The increase of NSCs content at neurodegenerative brain damage is associated with increased proliferation of these cells and subsequent differentiation in neuronal or 

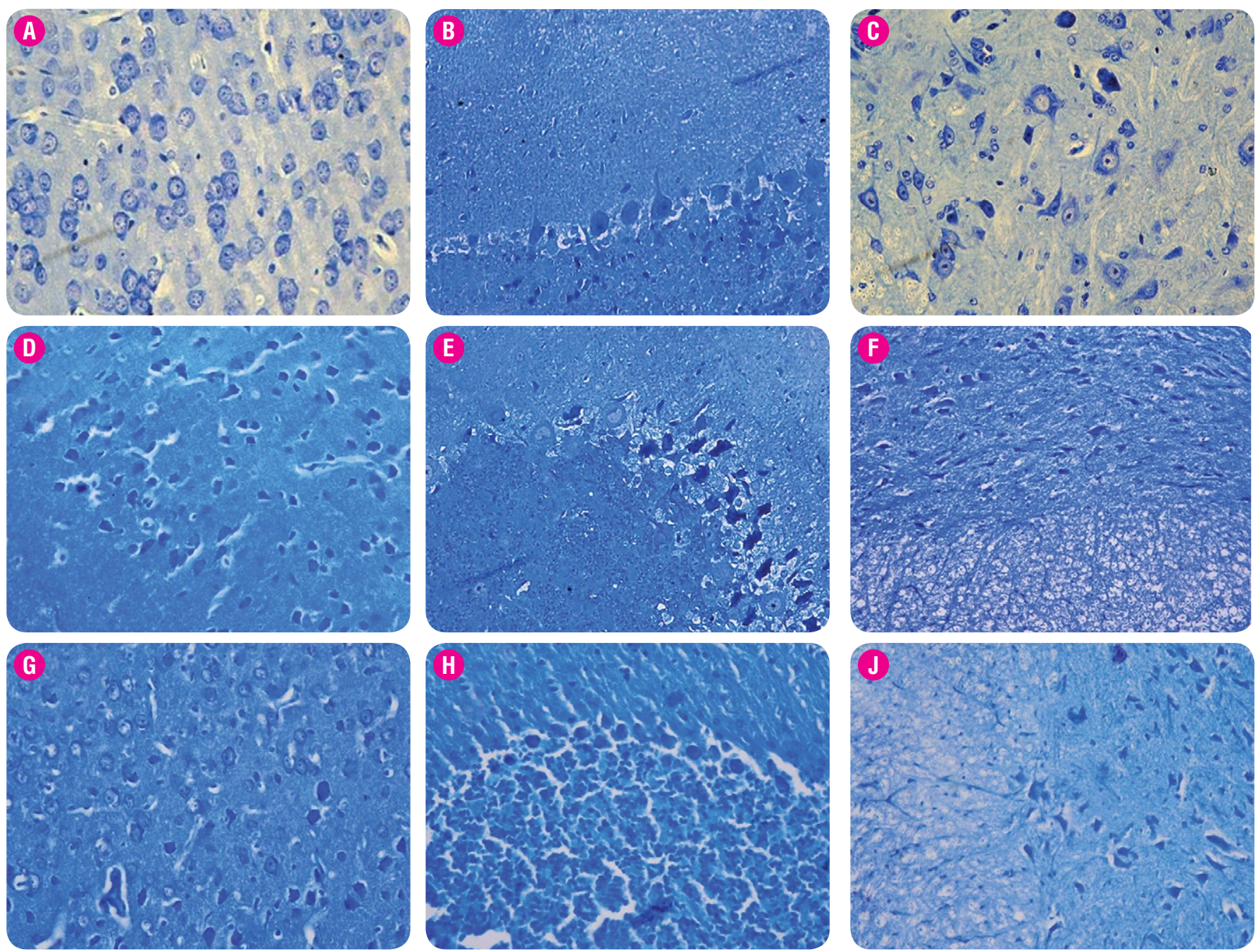

A Fig. 2. Microphotography histological sections of the neural tissue in experimental group mice. A, B, C - intact group; D, E, F-cuprizone group G, H, J - cuprizone + melatonin group. A, D, G - cerebral cortex; B, E, H-cerebellum (Purkinje cells); C, F, J - grey matter of the spinal cord (lumbar zone). Toluidine blue staining, oc. x10, ob. x40

glial directions to provide reparative regeneration of neural tissue $[2,3]$. After receiving the cuprizone in the several parts of the central nervous system, the proportion of neurons with destructive changes increases.

The development of destructive changes in neurons and myelin after 3 weeks of receiving cuprizone may be the result of the effects of factors of oxidative stress, the immune system and neuroinflammation. Indeed, it has been shown that in the brain of young mice receiving cuprizone, the content of MDA increases with the simultaneous decrease in the activity of antioxidant enzymes, and the number of active macrophages and T-lymphocytes increases. According to the literature, products of activated microglia/macrophages, some subpopulations of T-lymphocytes (in particular, free radicals, active forms of oxygen and nitrogen, proinflammatory cytokine IL-1 $\beta$, interferon- $\gamma$ and TNF- $\alpha$, and chemokines) can significantly change the functions of neural cells in the pathology of the nervous system $[4,5,28]$. Among T-lymphocytes, special attention is given to T-helpers, namely, T-helper type 17 , which synthesis products enhance cuprizone-induced death of oligodendrocytes [29]. According to our data, the number of $\mathrm{CD} 4^{+} \mathrm{T}$-cells in the brain of young mice with a cuprizone demyelination model is significantly increasing [30].

The result of damage to the neurons of the brain and spinal cord and myelin in the central nervous system at treatment with cuprizone is the development of motor and emotional activity disorders in mice. According to the literature data, motor neurons of the spinal cord inter- act with the cortex and cerebellum to provide motor activity; emotional behaviour is ensured by the interaction of the cerebral cortex with the parts of the limbic system and the hypothalamus [31].

We have shown that after the administration of melatonin, the number of neurons with destructive changes significantly decreases, and conversely, the number of unchanged neurons and neurons with moderate structural changes increases in the brain and spinal cord of the mice that received cuprizone. In animals that received cuprizone, melatonin also reduces the manifestations of demyelination [8]. According to our data, the remyelinating effect of melatonin on the cuprizone-demyelinated axons of cerebellar neurons is mediated by an increase in the Olig2 ${ }^{+}$cell $[32,33]$. As a result, positive structural changes in the CNS of animals with the cuprizone diet, which received melatonin, are accompanied by an improvement in suppressed motor and emotional behaviour.

The authors have shown that neuroprotective and remyelinating effect of melatonin in mice with pathology of the nervous system may be associated with its antioxidant, anti-inflammatory and anti-apoptotic properties $[7,8,34]$. We also found that in the brain of mice under the influence of melatonin, the number of T-lymphocytes, active macrophages, the content of MDA decreases and the activity of antioxidant enzymes increases. Moreover, according to our data, in mice with a cuprizone demyelination model receiving melatonin, there is an increase 


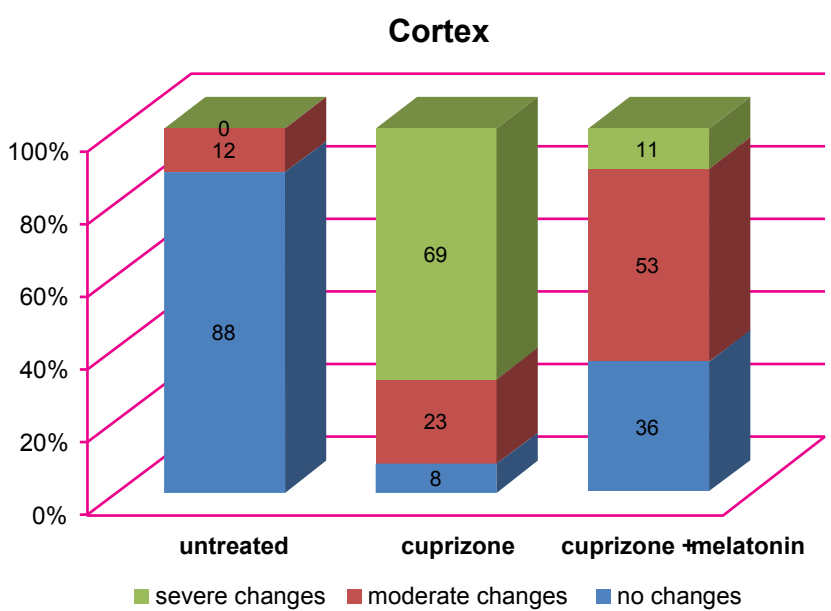

Cerebellum

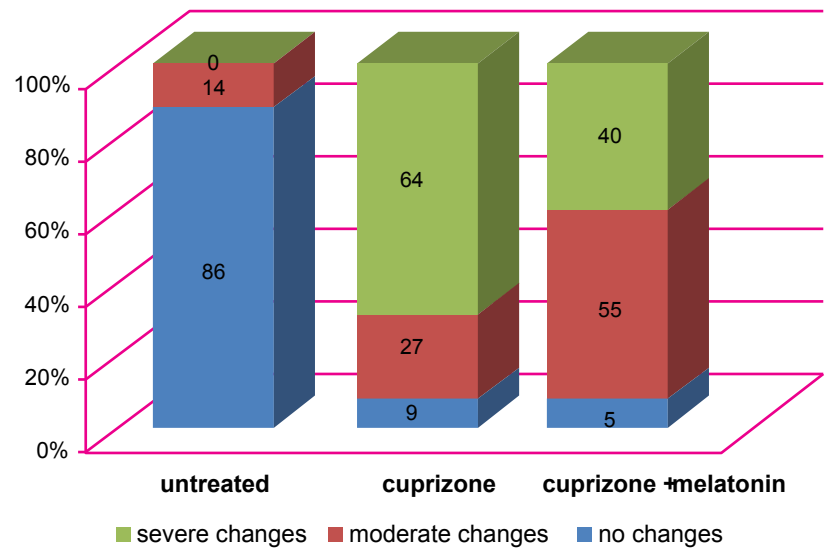

Spinal cord

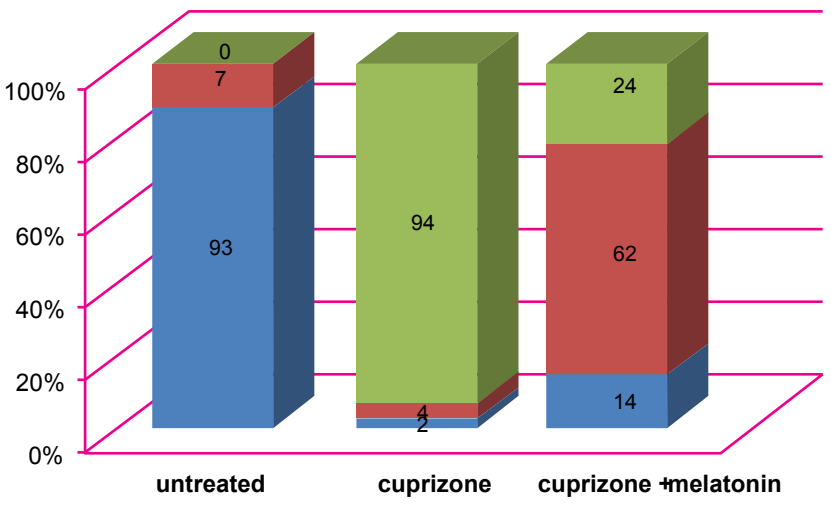

nevere changes moderate changes no changes

Fig. 3. Indices of morphometry of structural changes in neurons in 129/Sv mice with a cuprizone-induced demyelination model received melatonin

in the level of thymulin in the blood. The known ability of this hormone to influence the formation of subpopulations of T-lymphocytes, to change the activity of macrophages, to strengthen the synthesis of anti-inflammatory cytokines (IL-10) and to reduce the synthesis of proinflammatory cytokines (IL-1 $\beta$, IL-6, TNF-a, etc.) in the brain of animals with the experimental model of neuroinflammation [21,35]. At the same time, mice with a demyelination model show a supressive effect of melatonin on the formation of T-helpers type-17, which produce a pro-inflammatory cytokine IL-17 with damage to myelin of neuron axons $[29,36]$. Therefore, it can be assumed that the activation of the endocrine function of the thymus
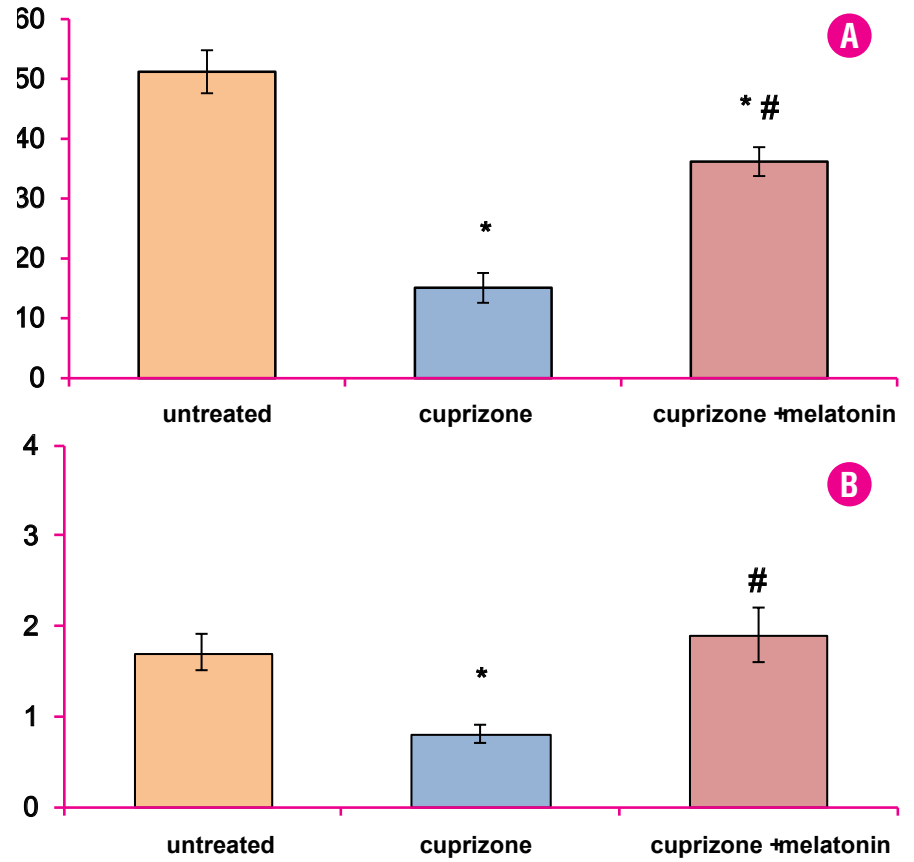

Fig. 4. Behavioural reactions in mice of experimental groups in the «open field» test: $\mathbf{A}$ - horizontal motor activity, $\mathbf{B}$ - emotional activity.

under the impact of melatonin in mice with a cuprizone model of demyelination is one of the ways of anti-inflammatory action of this hormone.

Activation of neurogenesis in the central nervous system is another possible way of protective effect of melatonin in the mice that received cuprizone. Thus, it has been shown that melatonin enhances the proliferation and differentiation of NSCs in the main areas of brain neurogenesis, as well as the synthesis of neurotrophic factors (brain-derived neurotrophic factor - BDNF, nerve growth factor - NGF) [37]. We have established a reduction in relative number of $\mathrm{Nestin}^{+}$cells in the brain of the mice with a cuprizone diet after the administration of melatonin to the level of intact animals. It is possible that such changes in the Nestin ${ }^{+}$cells can be explained by an increase in their differentiation in the neuronal direction, since the number of unchanged neurons simultaneously increase in such animals. A similar trend in the change in the number of such cells in the neurogenic area of the brain (olfactory bulb) with the simultaneous increase in the number of unchanged neurons in the middle brain was observed in animals with experimental hemiparkinsonism, which received melatonin $[23,38]$. In addition, exogenous melatonin increases the content of myelin-producing cells in the brain of the mice with a cuprizone demyelination model $[8,14,32,33]$. 


\section{CONCLUSION}

In mice with a cuprizone model of toxic demyelination, changes in the number of T-lymphocytes, active macrophages, MDA level and the activity of antioxidant enzymes in the brain corelated with violations of the structure of the central nervous system and behavioural reactions.

The protective effect of exogenous melatonin on structural and functional disorders of the central nervous system in animals with a cuprizone demyelination model is largely mediated by positive changes in the investigated factors of the immune system and antioxidant defense, as well as an increase in the blood level of the thymulin.

Melatonin may be a promising agent in cell therapy of demyelinating and neurodegenerative diseases of the central nervous system, which influences on the pathogenesis of these pathologies.

The study has been carried out within the project No. 0116 U000139 "The role of the cell and endocrine factors in the realization of the neuroprotective properties of the stem cells in the experimental damages of the nervous system" in the Institute of Genetic and Regenerative Medicine, National Academy of Medical Sciences of Ukraine (2016-2018).

\section{REFERENCES}

1. Mishchenko TS, Shulga OD, Bobryk NV, et al. Rozsiyaniy skleroz: global'ni perspektivi. [Multiple Sclerosis: Global Perspectives]. Ukr Med Chasopis - Ukr Med J. 2014; 101(3):84-87. [In Ukrainian]

2. Lindvall 0, Kokaia Z. Stem cells in human neurodegenerative disorders - time for clinical translation? JCI. 2010; 120(1):29-40.

3. Rybachuk O, Pivneva T. Contribution of neural stem cells to regeneration of the central nervous system. Int J Phy Path. 2014; 5(1):83-96.

4. Abdurasulova IN, Klimenko VM. Rol' immunnykh i glial'nykh kletok v protsessakh neyrodegeneratsii. [The role of immune and glial cells in the processes of neurodegeneration]. Med Akadem Zhurnal - Med Acad J. 2011; 11(1):12-29. [In Russian]

5. Gonzalez H, Pacheco R. T-cell-mediated regulation of neuroinflammation involved in neurodegenerative diseases. J Neuroinflammation. 2014; 11(201):11.

6. Cardinali DP, Esquifino Al, Srinivasan V, et al. Melatonin and the immune system in aging. Neuroimmunomodulation. 2008; 15(4-6):272-278.

7. Manchester LC, Coto-Montes A, Boga JA. et al. Melatonin: an ancient molecule that makes oxygen metabolically tolerable. J Pineal Res. 2015; 59(4):403-419.

8. Kashani IR, RaJabi Z, Akbari $M$, et al. Protective effects of melatonin against mitochondrial injury in a mouse model of multiple sclerosis. Exp Brain Res. 2014; 232(9):2835-2846.

9. Labunets IF, Rodnichenko AE, Utko NA, et al. Neyroprotektornoe vliyanie melatonina pri eksperimental'nykh modelyakh patologii nervnoy sistemy [Neuroprotective effect of melatonin in experimental models of the nervous system pathology]. Cell and organ transplantology. 2017; 5(2):241-242. [In Russian]

10. Gudi V, Gingele S, Skripuletz Th, et al. Glial response during cuprizon-induced de- and remyelination in the CNS: lessons learned. Front Cell Neurosci. $2014 ; 8$ (Article 73). $24 \mathrm{p}$.

11. Praet J, Guglielmetti C, Berneman Z, et al. Cellular and molecular neuropathology of the cuprizone mouse model: Clinical relevance for multiple sclerosis. J Neubiorev. 2014. 47. P. 485-505

12. Labunets IF, Melnik NO, Kuzminova IA, et al. Vpliv neyrotoksinu «kuprizon» na povedinkovi reaktsiï ta morfofunktsional'ni zmini neyroniv golovnogo ta spinnogo mozku u mishey. [Influence of neurotoxin «cuprizone» on behavioural reactions and morphofunctional changes of neurons of a brain and a spinal cord in mice]. Zh NAMN Ukraini - JNAMSU. 2014; 20(4):402-408. [In Ukrainian]

13. Labunets IF, Melnik NO, Kuzminova IA, et al. Patent Ukraïni na korisnu model' № 94458 u (UA), MPK G09B 23/28 «Sposib modelyuvannya strukturnikh zmin neyroniv tsentral'noï nervovoï sistemi pri demielinizuyuchikh zakhvoryuvannyakh (2006.01).» [Patent of Ukraine for Utility Model \#94458 u (UA), MPK G09B 23/28 «Method for modeling structural changes in neurons of the central nervous system in demyelinating diseases (2006.01)»]. Publ. 10.11.2014. Bul. 21. 3 p. [In Ukrainian]

14. Labunets IF. Struktura deyakikh organiv nervovoï ta imunnoï sistem za umov demielinizatsiï ta remielinizatsiï [Possibilities and prospects of the application of the in vivo and in vitro toxic cuprizone model for demyelination in experimental and clinical neurology (literature review and own research results)]. Ukraïns'kiy nevrologichniy zhurnal - Ukrainian Neurological Journal. 2018; 2:63-68. [In Ukrainian]

15. Labunets IF, Melnyk NO, Rodnichenko AE, et al. Cuprizone-Induced Disorders of Central Nervous System Neurons, Behavioral Reactions, Brain Activity of Macrophages and Antioxidant Enzymes in the Mice of Different Ages: Role of Leukemia Inhibitory Factor in their Improvement. J Aging Geriatr Med. 2017; 1(2). 8 p. Doi: 10.4172/ AGM.1000104.

16. Serra-de-Oliveira N, Boilesen SN, Prado de França Carvalho C, et al. Behavioural changes observed in demyelination model shares similarities with white matter abnormalities in humans. Behav Brain Res. 2015; 287:265-275

17. Labunets IF, Melnik NO., Rymar SYu. Patent na korisnu model’ № 104976 Ukraïna, MPK G09B23/28 «Sposib modelyuvannya regeneratsiï ushkodzhenikh neyroniv golovnogo mozku pri neyrodegenerativnikh zakhvoryuvannyakh [Patent for utility model \#104976 Ukraine, MPK G09B23/28 «Method of regeneration of damaged neurons of the brain in neurodegenerative diseases; \#u2015 09252; stat. 06.10.2015; publ. 25.02.2016, Bul. \#4. [In Ukrainian]

18. Jordan FL, Wynder HJ, Booth PL, et al. Method for the identification of brain macrophages/phagocytic cells in vitro. J Neurosci Res. 1990; 26(1):74-82.

19. Doklinichni doslidzhennya likars'kikh zasobiv (metodichni rekomendatsii). Pid red. O. V. Stefanova [Preclinical research of medicinal products (guidelines). By ed. OV Stefanov. Kyiv: Avicenna, 2001. 528 p. [In Ukrainian]

20. Bach JF, Bach MA, Blanot D, et al. Thymic serum factor (FTS). Bull Inst Pasteur (Paris). 1978. 76. P. 325-398.

21. Labunets IF, Rodnichenko AE, Vasyliev RG. Sposobnost' kletok-predshestvennits granulotsitov i makrofagov kostnogo mozga myshey raznykh liniy k obrazovaniyu koloniy in vitro pri izmenenii soderzhaniya timulina $v$ organizme i v kul'ture kletok. [Capacity of bone marrow granulocyte and macrophage precursors in mice of different strains for in vitro colony formation under changed thymuline level in the organism and cell cultures. Genes \& Cells. 2017; 12(2):97-103. [In Russian]

22. Uchiyama M, Mohara M. Determination of malonaldehyde precursor in tissues by thiobarbituric acid test.Anal Biochem. 1978; 86(1):271-278.

23. Labunets IF, Talanov SA, Vasilyev RG, et al. Thymic hormones, antioxidant enzymes and neurogenesis in bulbus olfactorius of rats with hemiparkinsonism: effect of melatoni. Int J Phy Path. 2016; 7(4):285-298.

24. Franco-Pons N, Torente M, Colomina M. T, et al. Behavioural deficits in the cuprizone-induced murine model of dymyelination/remyelination. Toxicol Lett. 2007; 30(3):205-213. 
25. Amikishieva AV. Povedencheskoe fenotipirovanie: sovremennye metody i oborudovanie [Behavioral Phenotyping: Modern Methods and Equipment]. Vestnik VoGiS Vavilov Journal of Genetics and Breeding. 2009; 13(3):529-542. [In Russian]

26. Fish GS. Animal models and human neuropsighiatric disorders. Behav Genet. 2007; 37:1-10.

27. Lakin GF. Biometriya [Biometrics]. Moskva: Vysshaya shkola - Moscow: High School, 1990. 352 p. [In Russian]

28. Taylor JM, Main BS, Crack PJ. Neuroinflammation and oxidative stress: co-conspirators in the pathology of Parkinson's disease. Neurochem Int. 2013; 62(5):803-19.

29. Kang Z, Liu L, Spangler R, et al. IL-17-induced Act1-mediated ignalling is critical for cuprizone-induced demyelination. J Neurosci. 2012; 32(4):8284-8292.

30. Labunets IF. Izmeneniya endokrinnoy funktsii timusa, makrofagov i T-limfotsitov golovnogo mozga u myshey raznogo vozrasta posle vvedeniya neyrotoksina kuprizona i tsitokina [Changes in the endocrine function of the thymus, macrophages and T-lymphocytes of the brain in mice of different ages after the administration of cuprozone neurotoxin and cytokine] Mezhdunarodnyy nevrologicheskiy zhurnal - International Neurological Journal. 2018; 98(4):114-120. [In Russian]

31. Ganong VF. Fiziologiya lyudini [Human physiology]. L'viv: Bak - Lviv: Bak, 2002. 784 p.

32. Rodnichenko A, Utko N, Labunets I. In vitro cuprizone model as a tool to study remyelination factors». 11th FENS Forum of neuroscience (7-11 July 2018, Berlin, Germany). Abstract number F18-0774.

33. Labunets IF, Rodnichenko AYe. Sposib otsinki remiєlinizuyuchogo efektu biologichno aktivnikh rechovin pri modelyuvanni in vitro demiєlinizuyuchikh ushkodzhen' klitin golovnogo mozku, zokrema mozochka [Method of evaluation of the remyelinating effect of bioactive substances in the simulation in vitro of demyelinating damages of brain cells, in particular, the cerebellum]. \#u2018 04204 from 17.04.2018. Decision on issuing a declarative patent for a utility model from 04.09.2018 \#23398/3y/18. [In Ukrainian]

34. Vakilzadeh $G$, Khodagholi $F$, Ghadin $T$, et al. The effect of melatonin on behavioural, molecular, and histopathological changes in cuprizone model of demyelination. Mol Neurobiol. 2016; 53(7):4675-4684.

35. Haddad JJ, Hanbali $L H$. The anti-inflammatory and immunomodulatory activity of thymulin peptide is NF-kB dependent and involves the downregulation of I kB-a. Am J Med Biol Res. 2013; 1(2):41-49.

36. Wurtman R. Multiple sclerosis, melatonin and neurobehavioral diseases. Front. Endocrinol. 2017. 8. Article 280. DOI:10.3389/fendo.2017.00280.

37. Sarlak G, Jenwitheesuk A, Chetsawang B, et al. Effects of melatonin on nervous system aging: neurogenesis and neurodegeneration. J. Pharmacol.Sci. 2013 ; 123:9-24.

38. Labunets IF, Chaikovsky YuB, Savosko SI, et al. Effects of melatonin on the behavioral indices and structural characteristics of cerebral and spinal neurons of rats with experimental hemiparkinsonism. Neurophysiology. 2018; 50(1):11-22.

\begin{tabular}{|l|c|}
\hline ARTILL ON THE SITE \\
\hline TRANSPLANTOLOG.ORG \\
\hline
\end{tabular}

The authors indicate no potential conflicts of interest. 